\title{
ANALISIS TECHNOLOGY ACCEPTANCE MODEL GENERASI MILLENIAL JAKARTA TERHADAP PENGGUNAAN E-MONEY
}

\author{
Randy Ramanda Sultan 1; Tuti Haryanti2; Laela Kurniawati \\ 1, 3 Program Studi Sistem Informasi \\ STMIK Nusa Mandiri \\ www.nusamandiri.ac.id \\ randyramanda.s@gmail.com,laela@nusamandiri.ac.id \\ 2Program Studi Sistem Informasi Akuntansi \\ Universitas Bina Sarana Informatika \\ www.bsi.ac.id \\ tuti.tty@bsi.ac.id

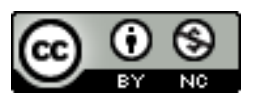

Ciptaan disebarluaskan di bawah Lisensi Creative Commons Atribusi-NonKomersial 4.0 Internasional.

\begin{abstract}
The development of Digital Technology that has penetrated almost all lines of human life In the field of Finance e-money is considered to have many benefits, mostly because the simplicity factor in using it. Bank Indonesia as the authority in charge of finance also launched Non-Cash Movement and conducted socializationsocialization to various layers of society. However, although socialization has been done, the acceptance of e-money in Indonesia is still low. Based on previous research, there are many factors that can influence the high acceptance and use of technology, among others, the perception of risk and Facilitating condition. This research was conducted to find out the influence of both external factors to the use of electronic money among jakarta millennial society conducted by testing the influence of these factors using approach Technology Acceptance Model (TAM). Subjects in this study amounted to 100 people. Data collection is done by distributing online questionnaire. Data analysis using SPSS for Windows version 16.0. Based on the research result, it is found that the two external factors have an effect on the acceptance of e-money.
\end{abstract}

Key Word: Technology Acceptance Model, TAM, SPSS, Millenial, Jakarta, E-money

Intisari-Perkembangan Teknology Digital yang telah merambah hampir seluruh lini kehidupan manusia Dibidang Keuangan e-money dianggap memiliki banyak manfaat, diantaranya dikarenakan faktor kesederhanaan dalam menggunakannya. Bank Indonesia sebagai otoritas yang berwewenang dalam bidang keuangan pun mencanangkan Gerakan Non-Tunai dan melakukan sosialisasi-sosialisasi ke berbagai lapisan masyarakat. Akan tetapi, walaupun berbagai sosialisasi telah dilakukan, penerimaan e-money di Indonesia masih tergolong rendah. Berdasarkan penelitian sebelumnya, terdapat banyak faktor yang dapat mempengaruhi tinggi rendahnya penerimaan dan penggunaan teknologi, antara lain persepsi resiko dan kondisi fasilitas. Penelitian ini dilakukan untuk mengetahui pengaruh kedua faktor-faktor eksternal tersebut terhadap penggunaan uang elektronik di kalangan masyarakat millennial jakarta yang dilakukan dengan menguji pengaruh faktor-faktor tersebut menggunakan pendekatan Technology Acceptance Model (TAM). Subjek dalam penelitian ini berjumlah 100 orang. Pengumpulan data dilakukan dengan menyebarkan kuisioner online. Analisis data menggunakan aplikasi SPSS for Windows versi 16.0. Berdasarkan hasil penelitian didapatkan bahwa Kedua faktor eksternal berpengaruh dalam penerimaan e-money.

Kata Kunci: Technology Acceptance Model, TAM, SPSS, Millenial, Jakarta, E-money

\section{PENDAHULUAN}

Berkembangnya teknologi informasi beberapa tahun belakangan ini telah membawa banyak perubahan terhadap berbagai lini kehidupan, tak terkecuali dibidang transaksi keuangan. Dengan adanya perkembangan dibidang teknologi informasi dan terus berkembangnya infrastruktur yang menunjang hal 
tersebut menyebabkan industri perbankan ikut melakukan inovasi-inovasi dalam hal pembayaran elektronik (Electronic Payment).

Berdasarkan Data yang dilansir oleh Bank Indonesi Pada bulan juni 2017, uang tunai yang beredar dalam arti luas (M2) mencapai Rp. 5,278 Trilliun (Divisi Statistik Moneter dan Fiskal, n.d.). Dari sekian banyak bank yang beroperasi di Indonesia, Bank Central Asia (BCA) adalah bank pertama yang menerbitkan e-money di Indonesia dengan menerbitkan produk e-money yang dikenal dengan kartu Flazz pada tahun 2009, lalu pada tahun yang sama BI meluncurkan peraturan mengenai uang elektronik untuk mengatur peredaran produk perbankan tersebut.

Berdasarkan data statistik Bank Indonesia (BI), dengan pertumbuhan nominal 216,46\%, volume transaksi uang elekronik meningkat $157,31 \%$ menjadi 330,67 juta transaksi dari November 2017 yang mencapai 128,51 juta transaksi (Bank Indonesia, 2017). Penyebab kenaikan volume dan nilai transaksi uang transaksi adalah meningkatnya jumlah uang yang beredar dimasyarakat. Sampai November 2018, jumlah uang elektronik yang beredar sebanyak 152,067 atau meningkat $33,72 \%$ dengan periode sama tahun sebelumnya sebanyak 113,72 juta.

Ada beberapa kelebihan e-money dibandingkankan uang fisik. Pertama, bisa melakukan berbagai transaksi tanpa membawa banyak uang fisik, Kedua bisa melakukan transaksi lebih cepat karena tinggal mengurangi nilai di emoney dengan nilai transaksi. Namun ada juga kekurangan e-money. Pertama, belum semua transaksi bisa memakai e-money karena e-money baru bisa dipakai di merchant yang bekerja sama dengan penerbit. Kedua, risiko seluruh uang hilang ketika pengguna kehilangan kartu (Rosanti \& Mustafa, 2018) atau piranti yang dipakai menyimpan e-money (Wibowo, Rosmauli, \& Suhud, 2015).

\section{BAHAN DAN METODE}

Penulis juga melakukan beberapa metode dalam penulisan ini sebagai proses penelitian data, guna untuk menunjang penyusunan penelitian ini. Beberapa metode yang digunakan penulis dalam mengumpulkan data adalah sebagai berikut :

\section{A. Observasi}

Melakukan penelitian langsung ke lapangan agar mempermudah dalam pengambilan data yang akan digunakan dalam penelitian.

\section{B. Studi Pustaka}

Dengan mempelajari buku-buku dan literatur-literatur yang relevan yang berhubungan dengan penelitian mengenai generasi millenial dan penggunaan e-money

\section{Wawancara}

Melakukan Wawancara kepada narasumber yang merepresentasikan generasi millenial Jakarta terutama yang menggunakan $e$-money agar mendapatkan data yang valid.

\section{Penelitian Terkait}

Hasil dari uji penelitian Identifikasi Faktor-Faktor Pada Penerimaan E-money Pada Kalangan Mahasiswa di Yogyakarta Menggunakan Technology Acceptance Model menunjukan bahwa dua faktor eksternal yang diujikan, yaitu Kondisi Fasilitas dan persepsi resiko berpengaruh terhadap penerimaan E-money pada responden yang di ujikan (Paramita, 2016).

Beberapa universitas di Indonesia telah menerapkan penggunaan e-money untuk transaksi ekonomi yang terjadi didalam kampus seperti penggunaan e-money dikantin kampus. Universitas Indonesia telah menerapkan penggunakaan e-money dikantin kampus sejak tahun 2013, sedangkan Fakultas ekonomika dan bisnis Universitas Diponegoro e-money hanya digunakan sebagai kartu identitas dan kartu hadir bagi mahasiswa dan dosen dan belum digunakan untuk aktivitas transaksi ekonomi dilingkungan FEB Undip (Ramadhan, Prasetyo, \& Irviana, 2016).

\section{Metode Pengumpulan Data}

Penelitian ini menggunakan kuesioner yang diberikan secara langsung kepada Subjek. Pengolahan data dalam penelitian ini dilakukan terhadap jawaban responden melalui penyebaran kuesioner yang telah diberikan. Pengujian hipotesis menggunakan perangkat lunak SPSS for Windows versi 16.0 .

Subjek pada penelitian ini adalah masyarakat Millenial Jakarta dengan kelompok umur antara 17 sampai 25 tahun. Sumber data diperoleh melalui penyebaran kuesioner Online yang dimulai dari tanggal 24 Desember 2017 sampai dengan tanggal 31 Desember 2017.

kuesioner yang disebar sebanyak 100 buah dan jumlah kuesioner yang kembali pun sebanyak 100 buah. Dari 100 kuesioner yang kembali 4 buah data tidak dapat diolah dan 96 data dapat diolah. Data yang tidak diolah dikarenakan subjek tidak memilik e-money

Penelitian ini dilakukan berdasarkan hasil jawaban atas kuesioner yang dapat diolah sebanyak 96 kuesioner. Berdasarkan tanggapan subjek atas hasil data kuesioner yang terkumpul, maka hasil dari identifikasi karakteristik subjek adalah sebagai berikut : 


\section{Gambaran Subjek Penelitian Berdasarkan Jenis Kelamin}

Proporsi subjek penelitian berdasarkan jenis kelamin yaitu 44 orang atau $45.8 \%$ pria dan 52 orang atau $54.2 \%$ wanita.

\section{Gambaran Subjek Berdasarkan Umur}

Proporsi terbanyak subjek penelitian berdasarkan jenis umur adalah kelompok umur 20-25 tahun dengan subjek sebanyak 44 orang atau 45.8\%. Kemudian kelompok umur 26-30 tahun dengan subjek sebanyak 25 orang atau 26\%, kelompok umur $<20$ tahun dengan batas umur bawah 17 tahun, dan 12 subjek atau 12,5\% dengan kelompok umur 31-35 tahun.

\section{Pendidikan}

Proporsi subjek penelitian berdasarkan tingkat pendidikan terbanyak ada tingkatan S1 (Sarjana) atau sederajat dengan jumlah subjek sebanyak 59 Orang atau 61.5\%. Tingkat pendidikan terbesar kedua adalah dari Pendidikan SMA/SMK yaitu sebesar 17 subjek atau 17.7\%. Tingkat Pendidikan S2 atau sederajat dan Diploma atau sederajat memiliki jumlah subjek yang sama yaitu 10 orang atau 10,4\%.

\section{Jenis Kartu}

Dari 96 subjek, 59 subjek atau 61.5\% menggunakan Kartu Flazz yang di publish oleh BCA, diikuti dengan E-Cash Mandiri sebanyak 42 subjek atau $43.8 \%$, E-toll card menempati posisi ketiga dengan subjek sebanyak 40 orang atau 41.7\%, di posisi keempat dan kelima T-Cash telkomsel dan JakCard Bank DKI memiliki jumlah subjek 24 dan 22 orang, atau 25\% dan 22,9\%. TapCash BNI memiliki jumlah subjek sebanyak 16 orang atau 16,7\%. Brizzi BRI memiliki jumlah subjek sebanyak 13 orang atau 13.5\%. dan terakhir 6 subjek atau 6.3\% memilih e-money yang diterbitkan oleh publisher lainnya. hasil tersebut didapat dari subjek yang memiliki kartu lebih dari satu jenis.

\section{Deskripsi Responden Berdasarkan Variabel}

Variabel-variabel yang digunakan dalam penelitian ini meliputi faktor persepsi resiko (Perceived of Risk (PoR)), kondisi fasilitas (Facilitating Condition (FC)) persepsi kemudahan penggunaan (Perceived of usefulness (PoU)), persepsi manfaat (Perceived Ease of Use (PEoU)), sikap terhadap penggunaan (Attitude toward using (ATU)), minat terhadap penggunaan (Behavioral Intention to Use (BItU)) \& penggunaan aktual (Actual Use (AU)) diuji secara statistik deskriptif.

Skor penelitian berdasarkan kriteria menurut skala likert ini akan diperoleh dengan rumus aritmatika mean yaitu:
Interval $=\frac{\text { Nilai maksimal }- \text { nilai minimal }}{\text { jumlah kelas }}=\frac{5-1}{1}=0.8$

$1.00-1.79=$ Sangat Rendah

$1.80-2.59=$ Rendah

$2.60-3.39=$ Sedang

$3.40-4.19=$ Tinggi

$4.20-5.00=$ Sangat Tinggi

Nilai rata-rata dari masing-masing variabel adalah 3,66 yang berada pada 3,40 - 4,19, yang berarti Perceived of Risk dipersepsikan responden termasuk tinggi. Nilai rata-rata ini menunjukan bahwa variabel PoR adalah tinggi.

Nilai rata-rata (mean) masing-masing variabel adalah 3,76, Nilai-nilai tersebut berada pada skala 3,40 - 4,19, yang berarti Facilitating Condition dipersepsikan responden termasuk tinggi. Nilai rata-rata ini menunjukan bahwa variabel FC adalah tinggi.

Nilai rata-rata (mean) masing-masing adalah 3,91, Nilai-nilai tersebut berada pada skala 3,40 - 4,19, yang berarti Perceived of Usefulness dipersepsikan responden termasuk tinggi. Nilai rata-rata ini menunjukan bahwa variabel PoU adalah tinggi.

Nilai rata-rata (mean) masing-masing variabel adalah 4,15, Nilai-nilai tersebut berada pada skala 3,40 - 4,19, yang berarti Perceived Ease of Use dipersepsikan responden termasuk tinggi. Nilai rata-rata ini menunjukan bahwa variabel PEoU adalah tinggi.

Nilai rata-rata variabel adalah 4,02 , Nilainilai tersebut berada pada skala 3,40 - 4,19, yang berarti Attitude toward Using dipersepsikan responden termasuk tinggi. Nilai rata-rata ini menunjukan bahwa variabel AtU adalah tinggi

Nilai rata-rata (mean) masing-masing variabel adalah 3.96, Nilai-nilai tersebut berada pada skala 3,40 - 4,19, yang berarti Behavioral Intention to Use dipersepsikan responden termasuk tinggi. Nilai rata-rata ini menunjukan bahwa variabel BItU adalah tinggi

Nilai rata-rata (mean) masing-masing variabel adalah 3,71, Nilai-nilai tersebut berada pada skala 3,40 - 4,19, yang berarti Actual Use dipersepsikan responden termasuk tinggi. Nilai rata-rata ini menunjukan bahwa variabel AU adalah tinggi

\section{HASIL DAN PEMBAHASAN}

\section{Hasil Uji Validitas Data}

Berdasarkan hasil data dari kuesioner yang telah diolah diketahui bahwa variabel PoR terdiri dari 4 pertanyaan yang keseluruhannya adalah valid dengan nilai signifikansi lebih kecil dari 0,05. Hal ini berarti bahwa setiap item pertanyaan PoR yang digunakan dalam penelitian 
ini mampu mengungkapkan sesuatu yang diukur pada kuesioner tersebut. Berdasarkan hasil data dari kuesioner yang telah diolah diketahui bahwa variabel FC terdiri dari 3 pertanyaan yang keseluruhannya adalah valid dengan nilai signifikansi lebih kecil dari 0,05. Hal ini berarti bahwa setiap item pertanyaan FC yang digunakan dalam penelitian ini mampu mengungkapkan sesuatu yang diukur pada kuesioner tersebut.

Berdasarkan hasil data dari kuesioner yang telah diolah diketahui bahwa variabel PoU terdiri dari 5 pertanyaan yang keseluruhannya adalah valid dengan nilai signifikansi lebih kecil dari 0,05. Hal ini berarti bahwa setiap item pertanyaan PoU yang digunakan dalam penelitian ini mampu mengungkapkan sesuatu yang diukur pada kuesioner tersebut.

Berdasarkan hasil data dari kuesioner yang telah diolah diketahui bahwa variabel PEoU terdiri dari 5 pertanyaan yang keseluruhannya adalah valid dengan nilai signifikansi lebih kecil dari 0,05. Hal ini berarti bahwa setiap item pertanyaan PEoU yang digunakan dalam penelitian ini mampu mengungkapkan sesuatu yang diukur pada kuesioner tersebut. Berdasarkan hasil data dari kuesioner yang telah diolah diketahui bahwa variabel AtU terdiri dari 3 pertanyaan yang keseluruhannya adalah valid dengan nilai signifikansi lebih kecil dari 0,05. Hal ini berarti bahwa setiap item pertanyaan AtU yang digunakan dalam penelitian ini mampu mengungkapkan sesuatu yang diukur pada kuesioner tersebut.

Berdasarkan hasil data dari kuesioner yang telah diolah diketahui bahwa variabel BItU terdiri dari 3 pertanyaan yang keseluruhannya adalah valid dengan nilai signifikansi lebih kecil dari 0,05. Hal ini berarti bahwa setiap item pertanyaan BItU yang digunakan dalam penelitian ini mampu mengungkapkan sesuatu yang diukur pada kuesioner tersebut. Berdasarkan hasil data dari kuesioner yang telah diolah diketahui bahwa variabel AU terdiri dari 3 pertanyaan yang keseluruhannya adalah valid dengan nilai signifikansi lebih kecil dari 0,05. Hal ini berarti bahwa setiap item pertanyaan AU yang digunakan dalam penelitian ini mampu mengungkapkan sesuatu yang diukur pada kuesioner tersebut.

\section{Hasil Uji Reliabilitas}

Peneliti menggunakan kategori reliabilitas sesuai dengan kaidah reliabilitas Guilford yaitu:

Tabel 1

Hasil Uji Relabilitas

Cronbach's Alpha N of Items

871

Sumber : (Sultan, Haryanti, \& Kurniawati, 2018)
Pada tabel 1 menunjukan nilai cronbach's alpha sebesar 0.871 yang artinya kuesioner tersebut termasuk kedalam kriteria reliabel. Hal ini menunjukan bahwa setiap item pernyataan yang digunakan mampu memperoleh data yang konsisten. Hal ini juga menunjukkan bahwa bila pernyataan itu diajukan kembali akan diperoleh jawaban yang relatif sama dengan jawaban sebelumnya.

\section{Uji Normalitas}

Uji normalitas dalam penelitian ini menggunakan uji Kolmogorov-Smirnov. Uji Kolmogorov-Smirnov adalah salah satu cara untuk menguji goodness fit. Dalam hal ini yang diperhatikan adalah tingkat kesesuaian antara distribusi nilai sampel (skor yang diobservasi) dengan distribusi teoritis tertentu (normal, uniform, atau position).

Berdasarkan hasil Penelitian One-Sample Kolmogorov-Smirnov Test dapat disimpulkan bahwa:

a. Nilai Kolmogorov-Smirnov $\mathrm{Z}$ variabel PoR adalah $1.59<1.97$. Dengan demikian Ho diterima. Hal ini berarti variabel PoR berdistribusi normal.

b. Nilai Kolmogorov-Smirnov Z variabel FC adalah $1.933<1.97$. Dengan demikian Ho diterima. Hal ini berarti variabel FC berdistribusi normal.

c. Nilai Kolmogorov-Smirnov Z. variabel PoU adalah $1.184<1.97$. Dengan demikian Ho diterima. Hal ini berarti variabel PoU berdistribusi normal.

d. Nilai Kolmogorov-Smirnov Z. variabel PEoU adalah $1.799<1.97$ Dengan demikian Ho diterima. Hal ini berarti variabel PEoU berdistribusi normal.

e. Nilai Kolmogorov-Smirnov Z. variabel AtU adalah 0,046 dan $1.373<$ 1.97. Dengan demikian Ho diterima. Hal ini berarti variabel AtU berdistribusi normal.

f. Nilai Kolmogorov-Smirnov Z. variabel BItU adalah $1.791<1.97$. Dengan demikian Ho diterima. Hal ini berarti variabel BItU berdistribusi normal.

g. Nilai Kolmogorov-Smirnov Z. variabel AU adalah $1.531<$ 1.97. Dengan demikian Ho diterima. Hal ini berarti variabel AUB berdistribusi normal.

\section{Uji Multikolinieritas}

Uji Multikolinieritas bertujuan untuk menguji apakah model regresi ditemukan adanya korelasi antar variabel independen. Model regresi yang baik mensyarakatkan tidak adanya multikolinieritas dengan cara melihat nilai Tolerance dan VIF (Variance Inflation Factor). Metode pengambilan keputusan yaitu jika semakin 
mendekati terjadinya masalah multikolinieritas. Dalam kebanyakan penelitian menyebutkan bahwa jika Tolerance lebih dari 0,1 dan VIF kurang dari

10 maka tidak terjadi multikolinieritas

Berdasarkan Hasil penelitian didapat bahwa nilai Variance Inflantion Factor (VIF) tidak lebih dari angka 10 untuk setiap variabel yang ditunjukkan dengan nilai VIF sebesar 1.252 untuk variabel PoR; 1,904 untuk variable FC; 2.677 untuk variabel PoU; 2,763 untuk variabel PEoU. Maka berdasarkan nilai VIF tidak ditemui masalah multikolonieritas antar variabel.

Berdasarkan Hasil penelitian didapat nilai Variance Inflantion Factor (VIF) tidak lebih dari angka 10 untuk setiap variabel yang ditunjukkan dengan nilai VIF sebesar 1.240 untuk variabel PoR; 1.921 untuk variable FC; 2.957 untuk variabel PoU; 2.844 untuk variabel PEoU dan 2.846 untuk variable AtU. Maka berdasarkan nilai VIF tidak ditemui masalah multikolonieritas antar variabel

Berdasarkan Hasil penelitian didapat bahwa nilai Variance Inflantion Factor (VIF) tidak lebih dari angka 10 untuk setiap variabel yang ditunjukkan dengan nilai VIF sebesar 1.251 untuk variabel PoR; 1.801 untuk variable FC; 2.773 untuk variabel PoU; 2.858 untuk variabel PEoU; 2.881 untuk variable AtU dan 2.360 untuk variabel BItU. Maka berdasarkan nilai VIF tidak ditemui masalah multikolonieritas antar variabel.

\section{Uji Regresi Linier Berganda Uji koefisien determinasi}

Koefisien determinasi (R2) bertujuan mengukur seberapa jauh kemampuan variabel independen (PoR, FC, PoU, dan PEoU ) dalam menjelaskan variasi variabel dependen (AtU, BItU dan AU). Nilai koefisien determinasi adalah antara nol dan satu. Penelitian ini menggunakan nilai R2, jika nilai R2 adalah sebesar 1 berarti fluktuasi variabel dependen seluruhnya dapat dijelaskan oleh variabel independen. Nilai $R$ berkisar dari 0 sampai 1, jika nilai $\mathrm{R}$ semakin mendekati angka 0 berarti semakin lemah kemampuan variabel independen untuk menjelaskan fluktuasi variabel dependen.

Nilai Adjusted R Square sebesar 0,664 atau $66,4 \%$ menunjukkan bahwa variabel PoR, PoU, PEoU, FC sebesar 68,5\%, sedangkan sisanya sebesar 31,5\% dijelaskan oleh faktor-faktor lain yang tidak disertakan dalam penelitian ini.

Nilai Adjusted $R$ Square sebesar 0,612 menunjukkan bahwa variabel PoR, FC, PEoU, PoU mempunyai pengaruh sebesar $63,7 \%$, sedangkan sisanya sebesar $36,3 \%$ dijelaskan oleh faktorfaktor lain yang tidak disertakan dalam penelitian ini.
Nilai Adjusted R Square sebesar 0,507 atau $50,7 \%$ menunjukkan bahwa variabel PoR, FC, PEoU, PoU, AtU, BItU sebesar 53,8\%, sedangkan sisanya sebesar $46,2 \%$ dijelaskan oleh faktorfaktor lain yang tidak disertakan dalam penelitian ini

\section{Uji Signifikansi Simultan (Uji F)}

Uji $\mathrm{F}$ digunakan untuk menguji pengaruh semua variabel independen yang dimasukkan dalam model regresi secara bersama-sama terhadap variabel dependen yang diuji pada tingkat signifikan 0,05 . Hasil uji $\mathrm{F}$ dapat dilihat pada tabel IV.27, jika nilai probabilitas lebih kecil dari 0,05 maka Ha diterima dan menolak Ho, sedangkan jika nilai probabilitas lebih besar dari 0,05 maka Ho diterima dan menolak Ha.

Hasil Uji Simultan F dapat dilihat pada tabel IV.27 bahwa nilai F diperoleh 32,252 dengan tingkat signifikansi 0,000 . Karena tingkat signifikansi lebih kecil dari 0,05 maka variabel PoR, FC, PoU, dan PEoU berpengaruh secara bersama-sama dan signifikan terhadap ATU.

Hasil Uji Simultan F dapat dilihat pada tabel IV.28 bahwa nilai F diperoleh 25,995 dengan tingkat signifikansi 0,000 . Karena tingkat signifikansi lebih kecil dari 0,05 maka variabel PoR, FC, PoU, PEoU serta AtU berpengaruh secara bersama-sama dan signifikan terhadap BItU.

Hasil Uji Simultan F dapat dilihat pada tabel IV.29 bahwa nilai F diperoleh 17,252 dengan tingkat signifikansi 0,000 . Karena tingkat signifikansi lebih kecil dari 0,05 maka variabel PoR, FC, PoU, PeoU,AtU dan BitU berpengaruh secara bersama-sama dan signifikan terhadap AU.

\section{Uji Signifikansi Parsial (Uji t)}

Uji t dilakukan untuk menguji pengaruh masing-masing variabel independen secara parsial terhadap variabel independen yang diuji pada tingkat signifikansi 0,05 . Hasil uji t dapat dilihat pada tabel 4.29, jika nilai probabilitas t lebih kecil dari 0,05 maka Ha diterima dan menolak Ho, sedangkan jika nilai probabilitas t lebih besar dari 0,05 maka Ho diterima dan menolak Ha.

\section{Hasil Hipotesis 1:}

\section{Pengaruh PoR terhadap PoU}

Hasil uji hipotesis 1 variabel PoR mempunyai tingkat signifikansi sebesar 0.000. Hal ini berarti variabel PoR berpengaruh dan bersignifikan terhadap PoU karena tingkat signifikansi yang dimiliki variabel PoR lebih kecil dari 0,05 .

\section{Hasil Hipotesis 2: \\ Pengaruh PoR terhadap PEoU}

Hasil uji hipotesis 2 variabel PoR mempunyai tingkat signifikansi sebesar 0.002 . Hal ini berarti variabel PoR berpengaruh dan bersignifikan terhadap PEoU karena tingkat 
signifikansi yang dimiliki variabel PoR lebih kecil dari 0,05.

\section{Hasil Hipotesis 3:}

\section{Pengaruh FC terhadap PoU}

Hasil uji hipotesis 3 variabel FC mempunyai tingkat signifikansi sebesar 0.000 . Hal ini berarti variabel FC berpengaruh dan bersignifikan terhadap PoU karena tingkat signifikansi yang dimiliki variabel FC lebih kecil dari 0,05 .

Hasil Hipotesis 4:

\section{Pengaruh FC terhadap PEoU}

Hasil uji hipotesis 4 variabel $\mathrm{FC}$ mempunyai tingkat signifikansi sebesar 0.000 . Hal ini berarti variabel FC berpengaruh dan bersignifikan terhadap PEoU karena tingkat signifikansi yang dimiliki variabel FC lebih kecil dari 0,05 .

Hasil Hipotesis 5:

\section{Pengaruh PEoU terhadap PoU}

Hasil uji hipotesis 5 variabel PEoU mempunyai tingkat signifikansi sebesar 0.000 . Hal ini berarti variabel PEoU berpengaruh dan bersignifikan terhadap PoU karena tingkat signifikansi yang dimiliki variabel PEoU lebih kecil dari 0,05 .

\section{Hasil Hipotesis 6:}

\section{Pengaruh PoU terhadap AtU}

Hasil uji hipotesis 6 variabel PoU mempunyai tingkat signifikansi sebesar 0.000 . Hal ini berarti variabel PoU berpengaruh dan bersignifikan terhadap AtU karena tingkat signifikansi yang dimiliki variabel PoU lebih kecil dari 0,05 .

\section{Hasil Hipotesis 7:}

\section{Pengaruh PEoU terhadap AtU}

Hasil uji hipotesis 7 variabel PEoU mempunyai tingkat signifikansi sebesar 0.000 . Hal ini berarti variabel PEoU berpengaruh dan bersignifikan terhadap AtU karena tingkat signifikansi yang dimiliki variabel PEoU lebih kecil dari 0,05 .

Hasil Hipotesis 8:

\section{Pengaruh PoU terhadap BItU}

Hasil uji hipotesis 8 variabel PoU mempunyai tingkat signifikansi sebesar 0.000 . Hal ini berarti variabel PoU berpengaruh dan bersignifikan terhadap BItU karena tingkat signifikansi yang dimiliki variabel PoU lebih kecil dari 0,05 .

\section{Hasil Hipotesis 9:}

\section{Pengaruh AtU terhadap BItU}

Hasil uji hipotesis 9 variabel AtU mempunyai tingkat signifikansi sebesar 0.000 . Hal ini berarti variabel AtU berpengaruh dan bersignifikan terhadap BItU karena tingkat signifikansi yang dimiliki variabel AtU lebih kecil dari 0,05 .

\section{Hasil Hipotesis 10: \\ Pengaruh BItU terhadap AU}

Hasil uji hipotesis 10 Variabel BItU mempunyai tingkat signifikansi sebesar 0.000 . Hal ini berarti variabel BItU berpengaruh dan bersignifikan terhadap AU karena tingkat signifikansi yang dimiliki variabel BItU lebih kecil dari 0,05 .

\section{Uji Analisis Korelasi Antar Variabel}

1. Korelasi antara PoR dan PoU

Berdasarkan perhitungan diperoleh angka antar variabel PoR dan FC sebesar 0,092. Untuk mentafsirkan angka tersebut digunakan kriteria sebagai berikut:

$0-0,25 \rightarrow$ : Korelasi sangat lemah (dianggap tidak ada)

$>0,25-0,5 \rightarrow$ : Korelasi cukup kuat

$>0,5-0,75$ : korelasi kuat

$>0,75-1 \rightarrow$ : Korelasi sangat kuat

Untuk pengujian lebih lanjut, maka diajukan hipotesis:

Ho; $\mathrm{p}=0$ : tidak ada hubungan (korelasi) yang signifikan antara dua variabel.

Ha; $p \neq 0$ : ada hubungan (korelasi) yang signifikan antara dua variabel.

Pengujian berdasarkan signifikan:

Jika probabilitas $>0,05$ maka Ho diterima

Jika probabilitas $<0,05$ Ho ditolak

Berdasarkan perhitungan, diperoleh angka antar variabel PoR dan PoU sebesar 0,382. Korelasi sebesar 0,382 mempunyai maksud hubungan antara variabel PoR dan PoU cukup kuat. Korelasi dua variabel tersebut mempunyai probabilitas sebesar $0,000<0,05$, maka telah cukup bukti untuk menolak Ho; $p=0$ dan menerima Ha; $p \neq 0$ sehingga korelasi bersignifikan.

2. Korelasi antara PoR dan PeoU

Berdasarkan perhitungan, diperoleh angka antar variabel PoR dan PEoU sebesar 0,319. Korelasi sebesar 0,319 mempunyai maksud hubungan antara variabel PoR dan PEoU cukup kuat dan. Korelasi dua variabel tersebut mempunyai probabilitas sebesar 0,002 $<0,05$, maka telah cukup bukti untuk menolak Ho; $p=0$ dan menerima Ha; $p \neq 0$ sehingga korelasi bersignifikan.

3. Korelasi antara FC dan $\mathrm{PoU}$

Berdasarkan perhitungan, diperoleh angka antar variabel FC dan PoU sebesar 0,618. Korelasi sebesar 0,618 mempunyai maksud hubungan antara variabel FC dan PoU kuat. Korelasi dua variabel tersebut mempunyai probabilitas sebesar $0,000<0,05$, maka telah cukup bukti untuk menolak Ho; $p=0$ dan menerima Ha; $p \neq 0$ sehingga korelasi bersignifikan. 
4. Korelasi antara FC dan PEoU

Berdasarkan perhitungan, diperoleh angka antar variabel FC dan PEoU sebesar 0,578. Korelasi sebesar 0,578 mempunyai maksud hubungan antara variabel FC dan PEoU kuat. Korelasi dua variabel tersebut mempunyai probabilitas sebesar $0,000<0,05$, maka telah cukup bukti untuk menolak Ho; $p=0$ dan menerima Ha; $p \neq 0$ sehingga korelasi bersignifikan

\section{Korelasi antara PoU dan PEoU}

Berdasarkan perhitungan, diperoleh angka antar variabel PoU dan PEoU sebesar 0,732 Korelasi sebesar 0,732 mempunyai maksud hubungan antara variabel PoU dan PEoU kuat. Korelasi dua variabel tersebut mempunyai probabilitas sebesar $0,000<0,05$, maka telah cukup bukti untuk menolak Ho; $p=0$ dan menerima $\mathrm{Ha} ; \mathrm{p} \neq 0$ sehingga korelasi bersignifikan 6. Korelasi antara PoU dan AtU

Berdasarkan perhitungan, diperoleh angka antar variabel PoU dan AtU Sebesar 0,684 Korelasi sebesar 0,684 mempunyai maksud hubungan antara variabel PoU dan AtU kuat. Korelasi dua variabel tersebut mempunyai probabilitas sebesar $0,000<0,05$, maka telah cukup bukti untuk menolak Ho; $p=0$ dan menerima Ha; $p \neq 0$ sehingga korelasi bersignifikan

\section{Korelasi antara PEoU dan AtU}

Berdasarkan perhitungan, diperoleh angka antar variabel PEoU dan AtU Sebesar 0,682 Korelasi sebesar 0,682 mempunyai maksud hubungan antara variabel PEoU dan AtU kuat. Korelasi dua variabel tersebut mempunyai probabilitas sebesar $0,000<0,05$, maka telah cukup bukti untuk menolak Ho; $p=0$ dan menerima Ha; $\mathrm{p} \neq 0$ sehingga korelasi bersignifikan 8. Korelasi antara PEoU dan AtU

Berdasarkan perhitungan, diperoleh angka antar variabel PEoU dan AtU Sebesar 0,682 Korelasi sebesar 0,682 mempunyai maksud hubungan antara variabel PEoU dan AtU kuat. Korelasi dua variabel tersebut mempunyai probabilitas sebesar $0,000<0,05$, maka telah cukup bukti untuk menolak Ho; $p=0$ dan menerima Ha; $p \neq 0$ sehingga korelasi bersignifikan 9. Korelasi antara PoU dan BItU

Berdasarkan perhitungan, diperoleh angka antar variabel PoU dan BItU Sebesar 0,595 Korelasi sebesar 0,595 mempunyai maksud hubungan antara variabel PoU dan BItU kuat. Korelasi dua variabel tersebut mempunyai probabilitas sebesar $0,000<0,05$, maka telah cukup bukti untuk menolak Ho; $p=0$ dan menerima Ha; $p \neq 0$ sehingga korelasi bersignifikan

10. Korelasi antara AtU dan BItU

Berdasarkan perhitungan, diperoleh angka antar variabel AtU dan BItU Sebesar 0,734 Korelasi sebesar 0,734 mempunyai maksud hubungan antara variabel AtU dan BItU cukup kuat. Korelasi dua variabel tersebut mempunyai probabilitas sebesar 0,000 <0,05, maka telah cukup bukti untuk menolak Ho; $p=0$ dan menerima Ha; $p \neq 0$ sehingga korelasi bersignifikan

11. Korelasi antara BItU dan AU

Berdasarkan perhitungan, diperoleh angka antar variabel BItU dan AU Sebesar 0,659 Korelasi sebesar 0,659 mempunyai maksud hubungan antara variabel BItU dan AU cukup kuat. Korelasi dua variabel tersebut mempunyai probabilitas sebesar $0,000<0,05$, maka telah cukup bukti untuk menolak Ho; $p=0$ dan menerima Ha; $p \neq 0$ sehingga korelasi bersignifikan.

Berdasarkan hasil penelitian terhadap beberapa konstruk dalam model penelitian ini, maka dapat digambarkan beberapa jawaban hipotesis yang telah dirumuskan sebagai berikut.

Tabel 2 Hasil Uji Hipotesis

\begin{tabular}{|c|c|c|c|c|c|}
\hline Hipotesis & $\begin{array}{l}\text { Hubung } \\
\text { an }\end{array}$ & $\begin{array}{l}\text { Hasil } \\
\text { Uji T }\end{array}$ & $\begin{array}{l}\text { Nilai } \\
\text { Peng } \\
\text { aruh }\end{array}$ & $\begin{array}{l}\text { Signifik } \\
\text { asi }\end{array}$ & $\begin{array}{l}\text { Keterang } \\
\text { an }\end{array}$ \\
\hline $\mathrm{H} 1$ & $\begin{array}{l}\text { PoR } \\
\text { terhada } \\
\text { p PoU }\end{array}$ & 4,011 & $\begin{array}{l}0,38 \\
2\end{array}$ & 0,000 & Diterima \\
\hline $\mathrm{H} 2$ & $\begin{array}{l}\text { PoR } \\
\text { terhada } \\
\text { p PEoU }\end{array}$ & 3,268 & $\begin{array}{l}0,31 \\
9\end{array}$ & 0,002 & Diterima \\
\hline H3 & $\begin{array}{l}\text { FC } \\
\text { terhada } \\
\text { p PoU }\end{array}$ & 6,860 & $\begin{array}{l}0,57 \\
8\end{array}$ & 0,000 & Diterima \\
\hline $\mathrm{H} 4$ & $\begin{array}{l}\text { FC } \\
\text { terhada } \\
\text { p PEoU }\end{array}$ & 7,612 & $\begin{array}{l}0,61 \\
8\end{array}$ & 0,000 & Diterima \\
\hline H5 & $\begin{array}{l}\text { PEoU } \\
\text { terhada } \\
\text { p PoU }\end{array}$ & $\begin{array}{l}10,40 \\
3\end{array}$ & $\begin{array}{l}0,73 \\
2\end{array}$ & 0,000 & Diterima \\
\hline H6 & $\begin{array}{l}\text { PoU } \\
\text { terhada } \\
\text { p AtU }\end{array}$ & 9,082 & $\begin{array}{l}0,68 \\
4\end{array}$ & 0,000 & Diterima \\
\hline H7 & $\begin{array}{l}\text { PEoU } \\
\text { terhada } \\
\text { p AtU }\end{array}$ & 9,049 & $\begin{array}{l}0,68 \\
2\end{array}$ & 0,000 & Diterima \\
\hline H8 & $\begin{array}{l}\text { PoU } \\
\text { terhada } \\
\text { p BItU }\end{array}$ & 7,170 & $\begin{array}{l}0,59 \\
5\end{array}$ & 0,000 & Diterima \\
\hline H9 & $\begin{array}{l}\text { AtU } \\
\text { terhada } \\
\text { p BItU }\end{array}$ & $\begin{array}{l}10,49 \\
0\end{array}$ & $\begin{array}{l}0,73 \\
4\end{array}$ & 0,000 & Diterima \\
\hline H10 & $\begin{array}{l}\text { BItU } \\
\text { terhada } \\
\text { p AU }\end{array}$ & 8,505 & $\begin{array}{l}0,65 \\
9\end{array}$ & 0,000 & Diterima \\
\hline
\end{tabular}

Sumber : (Sultan, Haryanti, \& Kurniawati, 2018)

Hasil uji T pada hipotesis 1, 2, 3, dan 4 pada tabel diatas menunjukan bahwa ada hubungan signifikan antara Perceived of Risk (PoR) dan Facilitating Condition (FC) dengan Perceived of Usefulness (PoU) dan Perceived Ease of Use (PEoU), dimana pada keempat nilai bersignifikansi. Penelitian menunjukan bahwa 
nilai konstruk eksternal Perceived of Risk (PoR) dan Facilitating Condition (FC) terhadap Perceived Usefulness (PU) dan Perceived Ease of Use (PEU) adalah signifikansi dengan nilai signifikans 0,000 dan 0,002

Hal ini ditunjukan dengan nilai rata-rata variabel Perceived of Risk (PoR) sebesar 3.66 pada rentang nilai $0-5$. Nilai rata-rata ini menunjukan bahwa variabel Perceived of Risk (PoR) adalah Tinggi. berpengaruh $73 \%$, minat terhadap penggunaan terhadap penggunaan aktual berpengaruh $66 \%$.

Berdasarkan penelitian yang telah dilakukan, diketahui bahwa faktor eksternal yang berpengaruh terhadap penerimaan e-money adalah kondisi fasilitas dan persepsi resiko. Faktor-faktor eksternal mempengaruhi perilaku, sikap dan minat seseorang atau subjek dalam menggunakan $e$-money

Tabel 3. Nilai Rata-Rata Konstruk

\begin{tabular}{llcl}
\hline Konstruk & Rata-Rata & Keterangan \\
\hline Perceived of Risk (PoR) & 3.66 & Bank Indon(tësiggi(2017). Uang Beredar Meningkat \\
\hline Facilitating Condition (FC) & 3.76 & pada Juni 2017. Retrieved from \\
\hline Perceived of Usefulness (PoU) & 3.91 & https://www.bi.go.id/id/ruang-media/info- \\
\hline Perceived Ease of Use (PeoU) & 4.15 & terbaru/Pages/Uang-Beredar-Meningkat- \\
\hline Attitude toward using (AtU) & 4.02 & pada-Juni-2017.aspx \\
\hline Behavioral Intention to Use (BItU) & 3.96 & \\
\hline Attitude toward using (AtU) & 3.71 & Divisi Statistik Moneter dan Fiskal. (n.d.). Analisis \\
\hline Sumber : (Sultan, Haryanti, \& Kurniawati, 2018) & Perkembangan Uang Beredar (M2) - Juni \\
& 2017 - Bank Sentral Republik Indonesia.
\end{tabular}

Dari beberapa jawaban yang diberikan oleh responden menunjukan bahwa rata-rata dari nilai kontruks PoR dan SK adalah tinggi. Dan ratarata dari konstruk diatas yang paling berdominan adalah tinggi.

Dari hasil gambaran kuesioner yang telah diisi oleh para responden menunjukan bahwa nilai rata-rata konstruk PoU sebesar 3,91 dan PEoU sebesar 4,15. gambaran ini menunjukan bahwa PEoU dan PoU tinggi.

Gambaran konstruk dari nilai rata-rata yang didapat dari konstruk AtU sebesar 4,02 hal ini menunjukan bahwa variabel AtU adalah tinggi, begitu juga dengan variabel BItU sebesar 3,96 adalah tinggi, variabel tentang AU memilik nilai rata-rata sebesar 3.71 , hal ini menunjukan bahwa variabel AU juga tinggi.

\section{KESIMPULAN}

Dari hasil penelitian, didapatkan kesimpulan berupa persepsi resiko terhadap persepsi kemudahan penggunaan berpengaruh 38\%, persepsi resiko terhadap persepsi manfaat berpengaruh $32 \%$, kondisi fasilitas terhadap persepsi berpengaruh 58\%, kondisi fasilitas terhadap persepsi manfaat berpengaruh $62 \%$, persepsi manfaat terhadap persepsi kemudahan penggunaan berpengaruh 73\%, persepsi kemudahan penggunaan terhadap sikap terhadap penggunaan berpengaruh $68 \%$, persepsi manfaat terhadap sikap terhadap penggunaan berpengaruh 68\%, persepsi kemudahan penggunaan minat terhadap penggunaan berpengaruh $60 \%$, sikap terhadap penggunaan terhadap minat terhadap penggunaan
Paramita, D. (2016). Identifikasi Faktor-Faktor Penerimaan E-Money Pada Kalangan Mahasiswa di Yogyakarta Menggunakan Acceptance Model, 8.

Ramadhan, A. F., Prasetyo, A. B., \& Irviana, L. (2016). Persepsi Mahasiswa Dalam Menggunakan E-money. Persepsi Mahasiswa Dalam Menggunakan E-Money, 13, 1-15.

Rosanti, N., \& Mustafa, M. (2018). Faktor Keengganan Pengguna Jasa Tol Beralih Menggunakan E-Money. Patria Artha Management Journal, 2(1), 23 - 40. https://doi.org/10.33857/PAMJ.V2I1.107

Sultan, R. R., Haryanti, T., \& Kurniawati, L. (2018). Laporan Akhir Penelitian Mandiri: Analisis Technology Acceptance Model Generasi Millenial Jakarta Terhadap Penggunaan EMoney. Jakarta.

Wibowo, S. F., Rosmauli, D., \& Suhud, U. (2015). Pengaruh Persepsi Manfaat, Persepsi Kemudahan, Fitur Layanan, Dan Kepercayaan Terhadap Minat Menggunakan E-Money Card (Studi Pada Pengguna Jasa Commuterline Di Jakarta). JRMSI - Jurnal Riset Manajemen Sains Indonesia, 6(1), 440. https://doi.org/10.21009/JRMSI.006.1.06 